\title{
Conservation status of Tanacetum baltistanicum medicinal endemic plant species of Gilgit Baltistan Pakistan \\ Raafiah Batool Chaudhry ${ }^{1 *}$, Shakil Ahmad ${ }^{2}$, Yamin Bibi ${ }^{1}$ and Abdul Qayyum ${ }^{3}$ \\ ${ }^{1}$ Department of Botany, PMAS Arid Agriculture University Rawalpindi \\ ${ }^{2}$ Prince Sultan University, Riyadh, Saudi Arabia \\ ${ }^{3}$ Department of Agronomy, The University of Haripur \\ Corresponding author Email: *raafiahbatool655@gmail.com
}

\begin{abstract}
Pakistan is blessed with a variety of plants that are being used for multiple purposes and medical uses. The uses of these plants related to their essential properties and proper uses are well known at the community level, while exploration at a medicinal scale is still needed. Anthropogenic activities and rise in population followed by poverty and ignorance, the significant plants are at risk. The comparatively more prosperous cover area of the herbaceous flora has vanished from about $60 \%$ of their habitats. The total flora of Pakistan, which is threatened, is more than $15 \%$ that includes many endemic species. These plants need to be preserved before they disappear because of excessive commercial harvest and local uses. Various exertions are mandatory for the proper documentation of plants, including recognizing endangered, endemic, and threatened country flora, which collectively forms the Red List. It required training of the local people for the proper conservation of the i) medicinally significant plants, ii) reduce anthropogenic pressure, and iii) Research and development of diverse methods for the conservation of endangered flora.
\end{abstract}

Keywords: Endemic, Baltistan, Conservation, Tanacetum baltistanicum

\section{Highlights:}

$>$ Explore the Tanacetum baltistanicum as a medicinal and endemic plant species in Pak region

$>$ The biomedical approaches of these plants as a precious source of medicines

$>$ The estimation of anthropogenic impact on biomedical activities on Tanacetum baltistanicum

\section{INTRODUCTION}

Plants are considered an essential component of global sustainability due to different ecosystem services of plants like fuel, food, medicine, and shelter. Healthy ecosystems with plant diversity are vital for the livelihoods and well-being of all humankind. The tremendous increase in human population, urbanization, habitat fragmentation and the increased dependency of the poor people on natural resources has significantly stressed wild plants that are rapidly disappearing (Woodruff, 2001). The rate of plant extinction has reached species per day, and this rate is 1000-10000 times more rapid than the natural extinction rate (Hilton-Taylor, 2000). According to Pujol et al. (2006), 60,000 to 100,000 species would disappear during the next 50 years if the trend remains constant. Almost half of the world's plant species are likely to be threatened by extinction if the assessment is made according to the categories and criteria of IUCN (Pitman, \& Jørgensen, 2002).

The precise evaluation of the conservation status of a plant is one of the most critical steps (Vischi, et al., 2004). To successfully prevent a plant from extermination. IUCN red list criteria and categories (IUCN 2001) are adapted worldwide to evaluate the conservation status in the wild, an approach for assessing and monitoring the status of biodiversity. These red list data categories are only applicable to wild populations of a taxon inside their natural range of occurrence. Furthermore, the conservation status is applicable within a specified geographical or political area because these categories belong to a specific or infraspecific level. Therefore, IUCN separately developed protocols for regional Red Data List assessment (IUCN, 2003).

The major problem for determining conservation status is that all the described plant taxa data are either limited or inappropriate; therefore, plants are considered poorly evaluated compared to animals. According to some estimates, the extinction risk of about $96 \%$ of all the described taxa is yet to be determined. (Sheth, et al., 2008). A total of 33798 vascular plants making $12.5 \%$ of the world's flora are listed as threatened globally. (Walter \& Gillet, 1998).

Pakistan has vast floral biodiversity containing about 6000 taxa and a large variety of species due to the country's diverse topographic, geographic, and climatic conditions (Breckle, \& Rafiqpoor, 2020; Hossain, et al., 2020). There are 128 pteridophytes, 23 gymnosperms, 1140 monocots, 576 types of grass, and 4492 taxa dicots. The forest cover of Pakistan is very low, and only $4 \%$ of the total land area is covered by forests, $5 \%$ of which is protected. The forests of the country are 
of different types such as a) tropical dry deciduous forests, b) littoral and swamp forests, c) sub-tropical broad-leaved evergreen forests, d) tropical thorn forests, sub-tropical pine forests, f) Himalayan dry temperate forests, g) Himalayan moist temperate forests, $\mathrm{h}$ ) subalpine forests and alpine scrub. The coniferous species are predominating, and about $40 \%$ of Pakistan's forests lie in Khyber Pakhtunkhwa. A significant source of wood in Pakistan is artificial forests. These are of four main types: farmland trees, irrigated plantations, linear and miscellaneous planting. About $90 \%$ of wood produced in the country is used as fuel (Ilyas, 2006; Saima et al., 2021).

\subsection{Major threats to biodiversity}

The biggest concern of ecologists in Pakistan regarding ecosystems is the continuous degradation of natural habitats and fragmentation. It affects equally rangelands, forests, freshwater, and marine ecosystems (Arif, et al., 2020; Raimi, et al., 2021). The continuous decline in many native species of plants and animals is of equal concern. These all factors have made some species extinct, many are internationally threatened, and more still are of national concern. It is leading to the continuous loss of domestic genetic diversity with the degradation of agro-ecosystems. Therefore, these are the areas that strongly need attention.

According to Biodiversity Action Plan Pakistan 1997, 4.8\% or 4.2 million ha of the country are covered by scrub forests, planted trees on farmlands. The total covered area may fall to 2.4 million ha (2.7\% coverage) after scrub forests and plantations (Dampha, 2020). More than $9 / 10$ of remaining coniferous forests have less than 50\% canopy cover. Less than 400,000 ha are covered by good quality coverage forests (GOP and IUCN, 2000). The declining rate of woody biomass is 4-6\% per year. It is expected that within the next ten years, this biomass could be consumed totally because the biomass consumption increases or decrease with the increase or decrease in population. Jabeen, (2006) found that the forests and rangelands are directly degraded by the rapidly increasing demand for fodder collection.

Rehman, \& Ghafoor, (2000) studied the human influence on the natural resources of Mount Elum, Swat. Analysis of the socio-economic profile revealed that land tenure and ownership conflict were the primary causes of the depletion of natural resources and ecological degradation, excluding i) deforestation, ii) fuelwood collection, iii) forest fires, iv) tourism, v) overgrazing, vi) terracing, vii) poverty, viii) ignorance, ix) lack of development initiatives, and $\mathrm{x}$ ) the ruthless exploitation of wildlife.

In a study about the status of 37 vascular plants belonging to 31 families, it was noted that: 7 species were confined to a single locality, exclusively in patches in a particular habitat, while 12 species were only rarely distributed in more than a single locality. Still, 18 species could be found in the whole tract (Fichtner, \& Wissemann, 2021). A decline was observed in the population size of these species due to the factors such as a decline in the area of occupancy, the extent of occurrence, loss of habitat, actual or potential level of exploitation, effects of introduced taxa, and attack of pathogens (Haq, 2011; Saima et al., 2021).

Moreover, another critical factor of biodiversity loss in Pakistan includes the lack of basic facilities like education, roads, etc., in remote areas. Therefore, the literacy rate is meager, with negligible female education. This low literacy rate has contributed significantly to the lack of awareness of local people. They are unaware of the importance of these indigenous forests to them and the ecosystem. Illiteracy has contributed significantly to the unsustainable use of forest resources in the area (Jabeen, 1999).

Conservation priorities on one side, forest cover constitutes 5.2\% (4.58million ha) of the country's area. Still, to the other, the country is highly dependent on trees and non-timber forest products (Irfan et al., 2020). A significant portion of the country's population depends on biological resources. Therefore the biological resources scarcity is a major concern for the country. Fuelwood still has an important place as the primary energy source in Pakistan, with $50 \%$ of the urban population and $90 \%$ of the rural population mainly relying on it (Maja, \& Ayano, 2021).

Currently, the study was aimed to highlight the conservation status over the past three decades. Conservationists, natural resource managers, and policymakers have recognized that the conservation of biological diversity depends upon protecting and managing intact natural habitats. Such recognition should be given greater importance and urgency to the international efforts to establish and maintain biospheres reserves, wildlife sanctuaries, national parks, forest reserves, and other protected areas.

\subsection{Past and present conservation scenario of Pakistan}

The record of conservation of natural resources in Pakistan is linked with its history of colonization and conquest. Over the past millennia, indigenous populations were forced into the mountains and foothills after the migration of invaders into the fertile plains of the sub-continent into the southeast, which entailed the clearing of forests for grazing and agriculture (Kothari, et al., 1998). 
An economic acceleration and social transformations took place in the post-colonization era. Industrial growth, population explosion, and agricultural commercialization continued to pressure the overall natural capital stock. The physical threats to the environment, especially the forest and river ecosystems, were further worsened by the collapse of traditional social structures. The economic opportunities were diversified by poverty, and the natural resource use was encouraged by the increased commercial value instead of conservation.

The designed management system for the specific purpose of conservation was unable to handle these changes. The multiple but conflicting interests of private developers, commercial loggers, hunters, governments, military agencies, hunters, and impoverished communities placed even more stress. The administration tended to select the least resistant path with a strict hand on the impoverished local communities colliding for personal profits and gains. Complex, awkward incentives disparate conservation like fines and penalties were selectively imposed related to increasing prices of timber, fuelwood, forest products, and erosion in the standard of living of the forest custodians. The critical inroads into forest resources began to be made by commercial and development groups, whose management could not oppose and cooperated. On the other hand, it targeted communities whose needs were of an essential subsistence nature and who had their rights and traditions been honored could have collaborated with the authorities in the sustainable management of forest resources (Baig et al., 2021).

\subsection{Plant locality and distribution}

Gilgit and Baltistan are located in the Northern Areas of Pakistan between 34.60-37.40 N and 740-77.50 E with 45224 sq. $\mathrm{km}$. The altitude varies from $\pm 1400 \mathrm{~m}$ to $8611 \mathrm{~m}(\mathrm{~K}-2)$. They are bordering China on the eastern side connected through a high Khunjerab pass $( \pm 4634 \mathrm{~m})$, having Central Asian states on its northern frontiers, Afghanistan on the northwestern border. In contrast, western and southern sides are delimited through Ghaizer, Astore, and occupied Jammu and Kashmir valleys. Administratively the project area has been divided into three districts i.e., Gilgit, Skardu, and Ghanche. These districts have been further subdivided into eight sub-divisions and twelve tehsils. The Human Population of the area is 546538; of this total, 95607 people were classified as urban while the rest of the population (450931) was classified as rural. Similarly, the annual population growth rate for the whole Northern Areas was estimated at 2.47\% (Ali \& Alam, 2015). Topography and Agriculture Gilgit and Baltistan are situated in the well-known mountain range, the Karakorum. Rugged mountains occupy most of the area. Many peaks above 7000m are found here, like Rakaposhi (7788m), Deran peak (7268m), and Godwin Austin $(\mathrm{K}-2,8611 \mathrm{~m})$. Baltoro glacier is one of the largest glaciers, extending for about $62 \mathrm{~km}$ and covering 529 sq. km (Baig et al., 2021). Due to the highly rugged mountainous topography, a large proportion of the region is uninhabitable. In most cases, the land consists primarily of small terraces. The agricultural system varies significantly with variations in altitude. Both the summer and winter crops are grown at lower altitudes, i.e., Gilgit town, lower Hunza, and Skardu. In comparison, at higher altitudes like Shagharthang, Askule, and Misgar, only summer crops are grown in which wheat, maize, barley, potatoes are common. Climate Climatic changes are vertically influenced due to high mountain ranges. The valleys have mild summer and cool winter, while mountaintops experience an arctic climate (Abbas et al., 2021). Temperatures in valley bottoms can range from nearly $400 \mathrm{C}$ in summer to less than $-100 \mathrm{C}$ in winter. Habitat: Ascending shrub up to $0.90 \mathrm{~m}$.

\subsubsection{Life Form}

Chaemophyte.

\subsubsection{Distribution}

Previously, this species has been reported from Hunza, Gilgit (Jutial Nullah), and Baltistan (Hushe River).

\subsubsection{Population Size}

Maximum of 133 mature individuals of the taxon was observed at Gilgit Baltistan. Two small spots were observed on Hone Mountain (Karimabad), carrying 29 and 82 mature individuals in Harai-e-Indil and Gheen Gun, respectively. These localities are approximately $0.5 \mathrm{~km}$ apart from each other. These subpopulations are highly restricted to small areas. Two mature individuals have been observed at the base of Hone Mountain in Ultar Nullah.

Similarly, three individuals were observed in Khunjerab National Park. Only 16 mature individuals were observed in Jutial Nullah. In the case of Kande (Baltistan), only two individuals were observed in 2003. While during 2004 and 2005 surveys no individual could found. 


\subsubsection{Habitat}

It grows on dry, rocky slopes and at the base of mountains along the streams banks. The dominant species for this habitat are Serephidium brevifolium, Rosa webbiana, and Hedysarum falconeri. Many other shrubs and herbs are also found in an association like Ribes alpestre, Lonicera heterophylla, Potentilla salvacifolia, Rheum tibetica, Androsace thomsonii, Morina sp Tanacetum artemesoides, and Astragalus peduncularis.

\subsubsection{Mode of Reproduction}

Only sexual reproduction was confirmed. Each mature individual on average contains 184 capitula, and each capitulum on average contains 26.4 achenes. The standard deviation for the number of capitula per individual is 87.25 , while the standard deviation for seeds per capitulum is 5.50 (Table $47 \& 48$ ).

\subsubsection{Area of Occupancy}

All known localities of the taxon collectively occupy a c. $2 \mathrm{~km} 2$ area.

\subsubsection{Occurrence}

The extent of occurrence is approximately an area of $1850 \mathrm{~km} 2$ (Table 49).

\subsection{Problems and threat of plants \\ 1.4.1. Threat}

Erosion: Those species that grow along the stream bank are affected due to erosion, particularly in the case of Ultar Nullah and Kande Nullah. In 2003 only two species were observed in Kande valley Baltistan, while in 2004 and 2005, no species could be observed in Kande valley. The main reason for this depletion was the flood. This species could be investigated from five localities. The observed highest population size of the taxon is 133 species. The estimated extent of occurrence is $1850 \mathrm{~km} 2$, and the area of occupancy is c. $2 \mathrm{~km} 2$. The degree of fragmentation, severe nature of erosion, and a small area of occupancy suggest that this species is Critically Vanishing. The genus Tanacetum belongs to the family Asteraceae. These species have received considerable attention in recent years due to their known biological properties. The genus Tanacetum (syn. Chrysanthemum), containing Ca. 200 species, is distributed throughout Europe and western Asia Tanacetum parthenium species, both raw and extracts, are being used in Insecticidal (Barnes, et al., 2007; Izumi, et al., 2008, Casida, 1980).

\subsubsection{Uses}

Extracts and different plants parts obtained from in the genus Tanacetum has been used to treat arthritis, asthma, constipation, dermatitis, earache, fever, headache, inflammatory conditions, insect bites, labor, menstrual disorders, potential miscarriage, psoriasis, spasms, stomach ache, swelling, tinnitus, toothache, vertigo, and worms.

\subsubsection{Insecticidal}

The plant T.baltistanicum also has been used as an insecticide. Bioactive compounds extracted from Tanacetum Parthenium have been used since ancient times for a variety of medicinal purposes. They recently have gained considerable prominence due to their ability to alleviate the symptoms of migraine headaches, arthritis, and psoriasis and to inhibit blood platelet aggregation (Kathirvel, 2021). Parthenolide and several related sesquiterpene lactones are considered to be responsible for these activities. Due to its emerging need and importance, the current research is paying great attention to this field of biological relevance (Romero, et al., 2021). The hexane extract of T.baltistanicum was found 100\% repellent against Sri Lankan weevil: Myllocerus undecimpustulatus undatus (Coleoptera: Curculionidae) on pear trees. In addition to this, no damage to any pods was observed during and after formulations. The only $1 \%$ aqueous solution (w/v) of four different extractives from T.baltistanicum showed various degrees of pest species reduction and insect-repellent activities. These diluted aqueous formulations from T.baltistanicum also offered the highest level of protection to both flowers and pods. The most active insecticidal fraction from T.baltistanicum was methanolic extractive with a 95\% mortality rate on 24 hours of treatment. The hexane extractive was most potent with $100 \%$ repellent activity against $M$. Undecimpustulatus undatus on leaves of pear trees. The hexane formulation was applied on pear trees (P.communis L.) infected by Sri Lankan weevil: M. Undecimpustulatus undatus. It was interesting that 5\% of $M$. Undecimpustulatus undatus were found dead after half an hour of the spray and the application of extractive, while the plants were found free from all insect pests in $24 \mathrm{~h}$ of the treatment. These are outstanding results, and this fraction of T.baltistanicum can now be used as a potent botanical insect repellant against $M$. Undecimpustulatus undatus. In addition to this, the application of this extractive can be expended to determine its toxicity against other insect pests in the future. 
Table: Extractive formulations of compounds on pest and their mortality level

\begin{tabular}{lllll}
\hline $\begin{array}{l}\text { Sr } \\
\text { NO. }\end{array}$ & $\begin{array}{l}\text { EXTRACTIVE } \\
\text { FORMULATIONS }\end{array}$ & PESTS & \multicolumn{2}{l}{$\begin{array}{l}\text { OBSERVATION AFTER TREATMENT (\% } \\
\text { MORTALITY) }\end{array}$} \\
\cline { 3 - 5 } & & AFTER SPRAY (30 MIN) & AFTER 24 HR \\
\hline 1 & HEXANE & SRI LANKAN WEEVIL & \multicolumn{1}{c}{10} \\
2 & ETHYL ACETATE & $\begin{array}{l}\text { MEALY CABBAGE APHIDS AND } \\
\text { CABBAGE CATERPILLAR }\end{array}$ & 5 & 90 \\
& WOOLY APPLE APHIDS & 10 & 85 \\
3 & METHANOL & WOOLY APPLE APHIDS & 15 & 95 \\
5 & WATER & WOOLY APPLE APHIDS & 10 & 90 \\
\hline
\end{tabular}

\subsection{Conservation strategies and management of plants}

On one side, forest cover constitutes $5.2 \%$ only (4.58million ha) of the country's area, but on the other, the country is highly dependent on trees and non-timber forest products (Shinwari et al., 2002). A significant portion of the country's population depends on biological resources; therefore, biological resources scarcity is a substantial concern for the country. Fuelwood still has an important place as the primary energy source in Pakistan, with 50\% of the urban population and $90 \%$ of the rural population mainly relying on it (Jawaid et al. 2021).

\subsubsection{Conservation Status}

Over the past three decades, conservationists, natural resource managers, and policymakers have recognized that the conservation of biological diversity depends upon protecting and managing intact natural habitats. Such recognition has given greater importance and urgency to the international efforts to establish and maintain biospheres reserves, wildlife sanctuaries, national parks, forest reserves, and other protected areas (Jawaid, et al., 2021).

\subsubsection{Ex-situ conservational process}

The removal of plants from their native habitats for translocation off-site to intensively managed facilities represent ex-situ conservation. This conservation strategy may use in botanical gardens, seed banks, or more sophisticated greenhouses. For several decades now, ex-situ conservation has been pursued internationally in a highly organized fashion through government support and institutional collaborations. Most of their attention has been directed at agricultural phylogenetic resources, but wild plants also are being maintained ex-situ on an increasingly large scale (Tuxill \& Nabha, 1998). World over different ex-situ conservation efforts is carried out. One major effort is the Millennium Seed Bank at the Royal Botanic Gardens, Kew, UK. An ex-situ conservation effort was made by cultivating 18 threatened plant species in lower Swat. Only 10 plant species i.e. Bergenia ciliata, Dioscorea deltoidea, Bistorta amplexicaulis, Primula denticulate, Valeriana jalamansa, Valeriana pyrolifolia, Viola biflora, Viola canescens, Salvia lanata and Berberis lyceum survived and acclimatized to a new habitat. In comparison, 8 species Colchicum luteum, Acorus calamus, Canha alba, Podophyllum emodi, Polygonatum verticilatum, Aconitum heterophyllum, Paeonia emodi, and Geranium wallichianum failed to germinate (Jawaid et al., 2021).

\subsubsection{In-situ conservation process}

The protection of plants in their native habitats, termed in-situ conservation, aims to keep intact the ecological relationships between species and, in some cases, cultural relationships between people and wild species. This kind of strategy may involve formally protected areas recognized by governments, such as sacred groves, springs, mountains, and reserves for medicinal plants where communities have decided that no other extractive activities are allowed. In most of the world, in situ conservation for useful plants has tended to be locally and informally organized. Efforts by governments or international organizations to promote in situ plant conservation are expanding. It is the best method for conserving genetic and plant resources, but its execution is not easy due to population pressure and resource constraints. The most effective way to conserve plants in their environment and ensure sustainable use of plant resources is to educate the people and provide them opportunities and better living standards. Ahmad et al. (2010) conducted a study about the ethnomedicinal uses of grasses 
in the Salt Range region of Northern Pakistan. They recommended that indigenous communities be trained to protect the endemic grass species using In -situ strategies for long-term sustainability.

\section{CONCLUSION}

The exploration of plant diversity beyond the community level for multiple purposes has threatened the plants and the whole ecosystem in different parts of Pakistan like other countries. There is a need to conserve these plants by proper documentation, monitoring, proper training of the locals, and reducing anthropogenic pressure on these plant resources for sustainability of nature. Protecting ecological regions is one of the powerful methods for biodiversity conservation. The plants have huge potential for biomedical and bio-drug operational processes as a future for the safety of human lives.

\section{Conflict of interest:}

There is no conflict of interest among Authors

\section{Acknowledgment:}

The authors are acknowledged to the Department of Botany, PMAS Arid Agriculture University Rawalpindi, and The University of Haripur for providing library and internet facility for searching required literature

\section{References}

Abbas, Z., Kousar, S., Aziz, M. A., Pieroni, A., Aldosari, A. A., Bussmann, R. W., ... \& Abbasi, A. M. (2021). Comparative Assessment of Medicinal Plant Utilization among Balti and Shina Communities in the Periphery of Deosai National Park, Pakistan. Biology, 10(5), 434.

Ahmad, A., Malik, M. I., \& Humayoun, A. A. (2010). Banking developments in Pakistan: A journey from conventional to Islamic banking. European Journal of Social Sciences, 17(1), 12-17.

Ali, D. S. I., \& Alam, J. (2015). Contribution to the Red List of the Plants of Pakistan: Endemic Phanerogams of Gilgit and Baltistan.

Arif, M., Zhang, S., Jie, Z., Charles, W., Sanelisiwe Mzondi, P., \& Li, C. (2020). Evaluating the effects of pressure indicators on riparian zone health conditions in the Three Gorges Dam Reservoir, China. Forests, 11(2), 214.

Baig, S., Khan, A. A., \& Khan, A. A. (2021). A time series analysis of causality between tourist arrivals and climatic effects for nature-based tourism destinations: evidence from Gilgit-Baltistan, Pakistan. Environment, Development and Sustainability, 23(4), 5035-5057.

Barnes, J. (2007). Herbal Medicines/Barnes J., Anderson L., Phillipson D.-3-rd ed. London: PhP.

Breckle, S. W., \& Rafiqpoor, M. D. (2020). The Hindu Kush/Afghanistan. In Plant Biogeography and Vegetation of High Mountains of Central and South-West Asia (pp. 43-91). Springer, Cham.

Casida, J. E. (1980). Pyrethrum flowers and pyrethroid insecticides. Environmental health perspectives, 34, $189-202$.

Dampha, N. K. (2020). Ecosystem services and coastal adaptation to climate change: An interdisciplinary science-based application in The Gambia (Doctoral dissertation, University of Minnesota).

Izumi, E., Morello, L. G., Ueda-Nakamura, T., Yamada-Ogatta, S. F., Dias Filho, B. P., Cortez, D. A. G., \& Nakamura, C. V. (2008). Trypanosoma cruzi: antiprotozoal activity of parthenolide obtained from Tanacetum parthenium (L.) Schultz Bip.(Asteraceae, Compositae) against epimastigote and amastigote forms. Experimental Parasitology, 118(3), 324-330.

Fichtner, A., \& Wissemann, V. (2021). Biological Flora of the British isles: Crataegus monogyna. Journal of Ecology, 109(1), 541-571. 
GoP, W. W. F. IUCN, 2000. Biodiversity Action Plan for Pakistan: A Framework for Conserving our Natural Wealth Imprint (Pvt) Ltd., Rawalpindi Cantt., Pakistan.

Haq, F. U. (2011). Conservation status of the critically endangered and endangered species in the Nandiar Khuwar catchment District Battagram, Pakistan. International Journal of Biodiversity and Conservation, 3(2), 27-35.

Hilton-Taylor, C. (2000). IUCN Red list of threatened species. IUCN Gland. Switzerland and Cambridge.

Hossain, M. I., Al Riyadh, Z., Rahman, M. A., Saha, S. R., \& Ferdousi, J. (2020). An overview on the current status and conservation practices of forest land and plant diversity of Bangladesh. Asian Journal of Research in Agriculture and Forestry, 1-12.

Ilyas, S. Z. (2006). Biogas support program is a reason for its success in Pakistan. American-Eurasian Journal of Scientific Research, 1(1), 42-45.

Irfan, M., Zhao, Z. Y., Panjwani, M. K., Mangi, F. H., Li, H., Jan, A., \& Rehman, A. (2020). Assessing the energy dynamics of Pakistan: prospects of biomass energy. Energy Reports, 6, 80-93.

IUCN, I. (2001). Red list categories and criteria: version 3.1. IUCN, Gland, Switzerland and Cambridge, UK.

IUCN Species Survival Commission. (2003). Guidelines for Application of IUCN Red List Criteria at Regional Levels. IUCN.

Jabeen, A. (1999). Ethnobotany of Fodder Species of Ayubia National Park, Nathia Gali, Its Conservation Status and Impacts on Environment (Doctoral dissertation, Quid-I-Azam University).

Jabeen, A. (2006). Fodder Management in and Around Ayubia National Park, Nathia Gali, Hazara Division, NWFP, Pakistan (Doctoral dissertation, Quaid-i-Azam University, Islamabad).

Jawaid A, Waseem A. Rafia, A. (2021). Plants as a natural resource of bioactive compounds for drug formulation to control infectious diseases. Journal Advances Nutrition Science Technology, 1(1), 11-18.

Kathirvel, P. (2021). Secondary Metabolites (Vol. 1). Darshan Publishers.

Kothari, A., Pathak, N., Anuradha, R. V., \& Taneja, B. (1998). Communities and conservation: natural resource management in South and Central Asia. Sage Publications Ltd.

Maja, M. M., \& Ayano, S. F. (2021). The Impact of Population Growth on Natural Resources and Farmers' Capacity to Adapt to Climate Change in Low-Income Countries. Earth Systems and Environment, 1-13.

Pitman, N. C., \& Jørgensen, P. M. (2002). Estimating the size of the world's threatened flora. Science, 298(5595), 989-989.

López-Pujol, J., Zhang, F. M., \& Ge, S. (2006). Plant biodiversity in China: richly varied, endangered, and in need of conservation. Biodiversity \& Conservation, 15(12), 3983-4026.

Raimi, M. O., Vivien, O. T., \& Oluwatoyin, O. A. (2021). Creating the Healthiest Nation: Climate Change and Environmental Health Impacts in Nigeria: A Narrative Review. Morufu Olalekan Raimi, Tonye Vivien Odubo \& Adedoyin Oluwatoyin Omidiji (2021) Creating the Healthiest Nation: Climate Change and Environmental Health Impacts in Nigeria: A Narrative Review. Scholink Sustainability in Environment. ISSN.

Rehman, M., \& Ghafoor, S. (2000). The natural resource and human ecology of Mount Elum District Swat. Consultancy Report. Pakistan: World Wildlife Fund Peshawar (WWF-P). 
Romero, E., Jones, B. S., Hogg, B. N., Rué Casamajo, A., Hayes, M. A., Flitsch, S. L., \& Schnepel, C. (2021). Enzymatic Late-Stage Modifications: Better Late Than Never. Angewandte Chemie International Edition.

Sheth, S. N., Lohmann, L. G., Consiglio, T., \& Jiménez, I. (2008). Effects of detectability on estimates of geographic range size in Bignonieae. Conservation Biology, 22(1), 200-211.

Shinwari, Z. K., Gilani, S. S., \& Akhlas, M. (2002). Sustainable harvest of medicinal plants at bar and Shinaki Valleys, Gilgit (Northern Pakistan). Consultancy Report: WWF-P, Gilgit.

Saima, N,, Anum K, Surryia M. (2021). Phenolic Profiling and Antimicrobial Studies of Fagonia cretica native to Pakistan. Journal Advances Nutrition Science Technology, 1(1), 19-32, 2021.

Tuxill, J., \& Nabhan, G. P. (1998). Plants and protected areas: a guide to in situ management. Stanley Thornes (Publishers) Ltd.

Vischi, N., Natale, E., \& Villamil, C. (2004). Six endemic plant species from central Argentina: an evaluation of their conservation status. Biodiversity \& Conservation, 13(5), 997-1008.

Walter, K. S., \& Gillet, H. J. (1998). IUCN Red List of treatened plants. Compiled by the World Conservation Union. Gland, Switzerland and Cambridge (UK).

Woodruff, D. S. (2001). Declines of biomes and biotas and the future of evolution. Proceedings of the National Academy of Sciences, 98(10), 5471-5476. 